\title{
Effect of Service Quality on Customer Satisfaction Prepaid Electricity at PT PLN (Persero) Region S2JB Palembang area, Rayon Mariana
}

\author{
Dina Nirwana Asri Putri, Zakaria Wahab, Ahmad Widad
}

\begin{abstract}
This study aims: (1) To determine impact of service quality, covers tangibles, reliability, assurances, responsiveness and emphaty simultanly to prepaid electricity customer satisfaction and (2) To determine impact of service quality, covers tangibles, reliability, assurances, responsiveness and emphaty partially to prepaid electricity customer satisfaction at PT. PLN (Persero) Region S2JB Rayon Mariana Palembang Area. The study design used is conclusive. The samples used were 100 respondens. To measure the influence between variables, used multiple linear regression and to test the hypotheses used to test the hypothesis $F$ and $t$. Results of the study are: (1) There is a signifikan effect on tangibles, reliability, assurances, responsiveness and emphaty simultanly to prepaid electricity customer satisfaction, (2) There is no signifikan effect on tangibles to prepaid electricity customer satisfaction, and (3) There is a signifikan effect on reliability, assurances, responsiveness and emphaty partially to prepaid electricity customer satisfaction at PT. PLN (Persero) Region S2JB Rayon Mariana Palembang Area.
\end{abstract}

Keywords: $\quad$ Service Quality, Tangibles, Reliability, Assurances, Responsiveness, and Customer Satisfaction

\section{INTRODUCTION}

PT PLN (Persero) is a state-owned company engaged in the electricity sector starting from the generation sector to electricity can be enjoyed directly by customers, both industrial and household customers. As a service provider company, the demands of customers for quality services are a need that must be fulfilled by PLN. Although currently PLN is a monopoly company that distributes electricity to general customers, PLN must continue to improve service excellence to its customers (Energy and Mineral Resources (ESDM) Regulation No. 27 of 2017). The regulation concerns the Service Quality Level (TMP) and costs associated with electricity distribution by PT PLN. In the TMP consists of 13 (thirteen) indicators in measuring the level of PLN service to its customers. One indicator of the PLN service quality is the error in reading the stand meter numbers on post-paid kWH meters. Therefore, in reducing errors in reading meters, PLN innovates to provide Prepaid Electricity or Smart Electricity (LPB) products. LPB is a prepaid electricity service that allows customers to control their own electricity usage according to their needs and capabilities. As with the top-up pulses on cellphones, on smart electricity systems, customers first purchase rechargeable electric pulses through ATM outlets or online electricity bill payment counters.

Revised Manuscript Received on August 14, 2019.

* Correspondence Author

Dina Nirwana Asri Putri*, Student postgraduate Magister Management at sriwijaya university, Indonesia.

Zakaria Wahab, Lecturer of Economic Faculty at Sriwijaya University Indonesia

Ahmad Widad, Lecturer of Economic Faculty at Sriwijaya University Indonesia

(c) The Authors. Published by Blue Eyes Intelligence Engineering and Sciences Publication (BEIESP). This is an open access article under the CC BY-NC-ND license (http://creativecommons.org/licenses/by-nc-nd/4.0/)
The demand for smart electricity usage at PT PLN (Persero) Mariana Rayon is increasing every year, both in terms of new applications and requests for regular customers who switch to prepaid electricity (migration). This can be seen from Table 1 below:

Table 1. Number of Prepaid Electricity Requests at PLN Rayon Mariana

\begin{tabular}{ccccc} 
No & Year & $\begin{array}{c}\text { New } \\
\text { Application }\end{array}$ & Migration & Total \\
\hline 1. & 2013 & 8.087 & 145 & 8.232 \\
2. & 2014 & 11.855 & 355 & 12.210 \\
3. & 2015 & 5.346 & 1.623 & 6.969 \\
4. & 2016 & 4.008 & 1.003 & 5.011 \\
5. & 2017 & 6.960 & 5.488 & 12.448 \\
\hline & Total & $\mathbf{3 6 . 2 5 6}$ & $\mathbf{8 . 6 1 4}$ & $\mathbf{4 4 . 8 7 0}$ \\
\hline
\end{tabular}

Source : AP2T PLN Tahun 2013 - 2017

Based on Table 1, it can be seen that the prepaid electricity application is increasing. This underlies PLN to continue to improve its services. LPB is inseparable from the new problems that were caused. The number of electricity complaints can be seen in Table 1 below:

Table 2. Reports on the Number of Complaints Prepaid Electricity Customer

\begin{tabular}{clcccc}
\hline \multirow{2}{*}{ No. } & \multirow{2}{*}{ Month } & \multicolumn{4}{c}{$\begin{array}{c}\text { Number of Complaints Prepaid } \\
\text { Electricity Customer }\end{array}$} \\
\cline { 3 - 6 } & & $\mathbf{2 0 1 4}$ & $\mathbf{2 0 1 5}$ & $\mathbf{2 0 1 6}$ & $\mathbf{2 0 1 7}$ \\
\hline 1 & January & 0 & 6 & 0 & 6 \\
2 & Pebruary & 0 & 3 & 1 & 2 \\
3 & March & 0 & 2 & 8 & 1 \\
4 & April & 0 & 3 & 7 & 4 \\
5 & May & 0 & 3 & 1 & 3 \\
6 & June & 2 & 5 & 3 & 0 \\
7 & July & 2 & 5 & 2 & 4 \\
8 & August & 1 & 4 & 3 & 0 \\
9 & September & 1 & 0 & 1 & 7 \\
10 & October & 1 & 0 & 3 & 2 \\
11 & November & 0 & 1 & 4 & 5 \\
12 & Desember & 3 & 1 & 6 & 5 \\
\hline \multicolumn{7}{c}{ Total } & $\mathbf{1 0}$ & $\mathbf{3 3}$ & $\mathbf{3 9}$ & $\mathbf{4 0}$ \\
\hline
\end{tabular}

Source: Report APKT PLN Rayon Mariana years 2014 2017

Based on the data in Table 2 above, it can be seen that the number of prepaid customer complaints increases every year. The complaints were caused by several things, namely procedures and constraints in filling tokens, damage to $\mathrm{kWh}$ meters, unstable voltage, transparency of costs and time to handle the interference.

\section{Published By:}

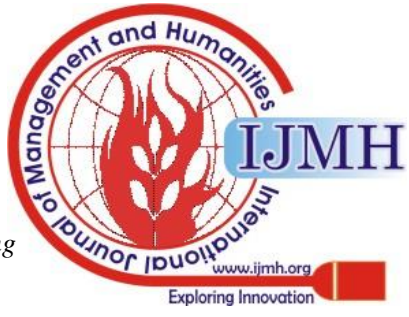




\section{Effect of Service Quality on Customer Satisfaction Prepaid Electricity at PT PLN (Persero) Region S2JB}

Palembang area, Rayon Mariana

The creation of good service quality will certainly create satisfaction with service users. Own service quality must begin with customer needs and end at the customer's perception or judgment. This means that good quality is not seen from the perception of the service provider, but based on customer perceptions of service quality is a comprehensive assessment of the superiority of a service. So that customer satisfaction can be achieved by providing good quality. Based on this background it is the basis for conducting research with the aim of knowing the effect of service quality which includes tangibles, reliability, assurances, responsiveness and empathy for prepaid customer satisfaction (LPB) at PT. PLN (Persero) Region S2JB Area Palembang Rayon Mariana.

\section{Service Quality} 282) define service quality as the expected level of excellence and control over the level of excellence to meet customer desires. If the services received or recommended are as expected, service quality is perceived as good and satisfying. According to Zeithaml and Bitner (2003) service (service) is an act, process, and performance.

One of the service quality approaches that are often used as a reference in marketing research is the SERVQUAL (Service Quality) model developed by Parasuraman, Zeithmal, and Berry (1988) in a series of research on six service sectors: repair, household appliances, credit cards, insurance and retail banking. According to Parasuraman, et. al., (1990; in Fitzsimmons and Fitzsimmons, 1994; Zeithaml and Bitner, 1996), five main dimensions of service quality are: tangible, reliability, responsiveness, assurance, and empathy. Customer Statisfacton

According to Kotler (2009) Satisfaction is a level of feeling where someone states the results of the comparison between the work products / services received with what is expected. According to Richard F. Gerson (2004: 5), a customer will feel satisfied if his needs, in fact or only presuppositions, are met or exceed his expectations. According to Kotler quoted by Tjiptono (1996: 148) there are four methods for measuring customer satisfaction, namely: system complaints and suggestions, customer satisfaction surveys, ghost shopping, and lost customer analysis. According to Tjiptono (2000: 101), the factors measuring customer satisfaction include: overall customer satisfaction, customer satisfaction dimensions, confirmations of expectation, repurchase intention, willingness to recommend (willingness to recommend), and customer dissatisfaction

\section{Customer Satisfaction and Service Quality}

According to Fornell in Sunyoto, 2012, quality has a very close relationship with customer satisfaction, namely quality that provides encouragement for customers to enhance strong relationships with the company. By providing good service quality and creating customer satisfaction, many benefits are received by the company, such as the creation of customer loyalty and preventing the transfer of customers, reducing customer sensitivity to prices, reducing promotional costs, reducing operating costs caused by an increase in the number of customers, increasing advertising needs and increase business success.

Conceptual framework

\section{LITERATURE REVIEW}

According to Parasuraman, et al. (1988) in Tjiptono (2014;

The conceptual framework used in this study, as presented in the picture as follows:

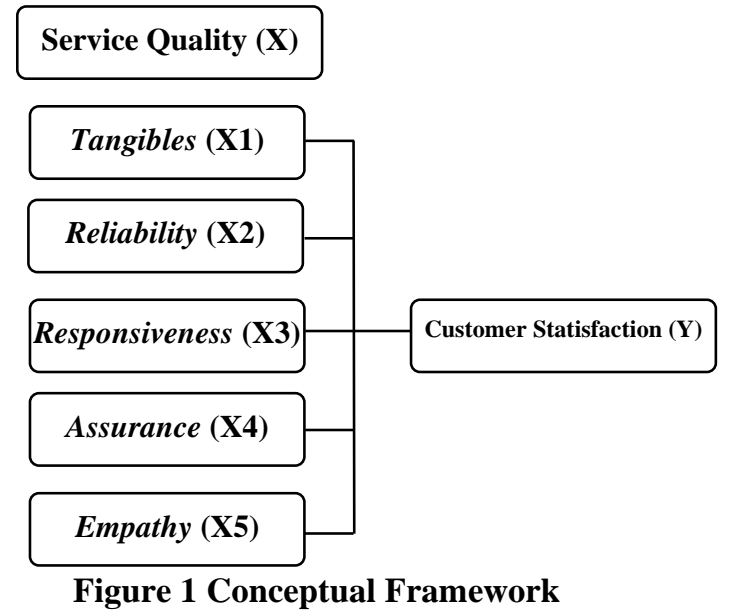

\section{Hipotesis}

$\mathrm{H1}$ : It is assumed that service quality is a variable of reliability, responsiveness, assurance (Assurance), empathy (empathy), and tangible evidence simultaneously have a significant effect on the satisfaction of prepaid electricity customers in PT. PLN (Persero) Region S2JB Area Palembang Rayon Mariana.

H2: Alleged dimensions of service quality include reliability, responsiveness, assurance (Assurance), empathy (empathy), and partial physical evidence (tangible) affect customer satisfaction PT. PLN (Persero) Region S2JB Area Palembang Rayon Mariana.

\section{RESEARCH METHODOLOGY}

The research design used is conclusive causal research. This design explains the relationship between variables through testing hypotheses, where there are in dependent variables (variables that influence) and dependent (influenced). The population in this study were prepaid electricity customers (LPB) PT PLN (Persero) Rayon Mariana as many as 53,843 customers per October 31, 2017. And the samples used in this study were 100 respondents. The sampling technique uses non probability sampling methods and sample determination using purposive sampling method. The data collection method used is a questionnaire distributed directly to designated prepaid customers. The analysis technique used in this study uses validity and reliability tests. In data, the technique used uses multiple linear regression analysis so that it makes it easy for users to enter more than one variable, indicated by the following equation:

$$
Y=a+b_{1} X_{1}+b_{2} X_{2}+b_{3} X_{3}+b_{4} X_{4}+b_{5} X_{5}+e
$$

Where Y is Customer Satisfaction, a as a constant, b1- b5 is a regression coefficient, $\mathrm{X} 1$ as a variable of Reliability, X2 as a Responsiveness variable, $\mathrm{X} 3$ as a Assurance variable (Assurance), X4 as Empathy variable, X5 as a variable of Physical Evidence (Tangible) and e as the Error Level.

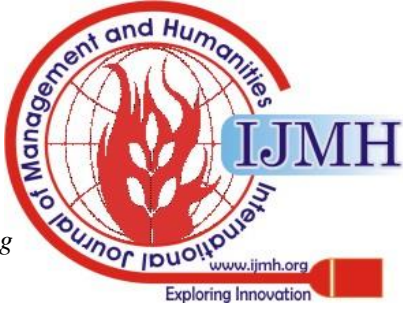




\section{Hypothesis testing}

Testing the hypothesis used is in the form of a simultaneous test ( $\mathrm{F}$ test) and a partial test ( $\mathrm{t}$ test). The $\mathrm{F}$ test is used to find out how much the independent variables (X1, $\mathrm{X} 2, \mathrm{X} 3, \mathrm{X} 4$, and $\mathrm{X} 5$ ) together influence the dependent variable $(Y)$. The $t$ test aims to determine how much the independent variables (X1, X2, X3, X4, and X5) influence partially on the dependent variable $(\mathrm{Y})$, assuming the other variables are constant.

\section{RESULT}

\section{Research Instrument Testing Results}

The validity test results explain that the data used in the Tangibles (X1), Reliability (X2), Responsiveness (X3), Assurance (X4), Empathy (X5) and Customer Satisfaction (Y) produce a value of $r$-count $>$ r-table, then the items in these variables are declared valid at the $5 \%$ real level and can be used in subsequent tests. The reliability test results explain that the value of Cronbach's Alpha variable is Tangibles (X1), Reliability (X2), Responsiveness (X3), Assurance (X4), Empathy (X5) and Customer Satisfaction (Y), above the number 0.700; which means that all the variables used in this study are declared reliable and can be used in subsequent tests.

\section{Classical Assumption Test Results}

Data on Tangibles (X1), Reliability (X2), Responsiveness (X3), Assurance (X4), Empathy (Emphaty) (X5) and Customer Satisfaction (Y ) has been distributed normally, there is no multicollinearity, and there is no heterocedasticity, so it is feasible to be analyzed by multiple linear regression.

\section{Analysis of Multiple Linear Regression}

Based on the results of regression testing using the SPSS program assistance obtained the results of multiple linear regression tests, namely as follows:

Table 3. Results of Testing Multiple Linear Regression and Hypothesis $\mathbf{t}$

\begin{tabular}{lccccc}
\hline & $\begin{array}{c}\text { Unstandardized } \\
\text { Coefficients }\end{array}$ & $\begin{array}{c}\text { Standardize } \\
\text { d } \\
\end{array}$ & B & \multicolumn{3}{c}{$\begin{array}{c}\text { Std. } \\
\text { Coefficients }\end{array}$} & Beta & T & Sig. \\
\cline { 2 - 5 } & & & & \\
\hline (Constant) & 3,256 & 0,352 & & 6,562 & 0,000 \\
Tangibles & 0,520 & 0,197 & 0,525 & 4,896 & 0,000 \\
Realibility & 0,753 & 0,154 & 0,714 & 6,216 & 0,000 \\
Responsiv & 0,646 & 0,195 & 0,603 & 5,727 & 0,000 \\
eness & & & & & \\
Assurance & 0,805 & 0,183 & 0,817 & 7,753 & 0,000 \\
Empathy & 0,698 & 0,174 & 0,593 & 5,994 & 0,000 \\
\hline Source
\end{tabular}

\section{Source: Data Processing Results}

Based on Table 3. above, a multiple linear regression equation can be formed, as follows :

$$
\begin{gathered}
Y=\alpha+\beta_{1} . X_{1}+\beta_{2} . X_{2}+\beta_{3} . X_{3}+\beta_{4} . X_{4}+\beta_{5 .} X_{5}+e \\
Y=3,256+0,520 . X 1+0,753 . X 2+0,646 . X 3+0,805 . X 4+ \\
\text { 0,698.X5 }
\end{gathered}
$$

Based on the multiple linear regression equation model that has been formed as mentioned above, it can be interpreted the effect of each independent variable on the dependent variable.

The constant value $(\alpha)$ is 3.256 , which means that if the service quality free variable $=0$, then the value of the dependent variable will be 3.256. In other words, if the quality of service does not give effect, customer satisfaction will still be worth 3,256.

The regression coefficient value of the Physical Evidence variable is 0.520 . A positive sign on the physical evidence variable indicates that the physical evidence variable has a positive influence on customer satisfaction of $52.1 \%$. Reliability variable regression coefficient value of 0.753 . This means that the variable Reliability affects the Customer Satisfaction variable (Y) of $75.3 \%$ (directly proportional) compared to other variables.

Regression coefficient value of the Keresponsifan variable is 0.646. This means that the Responsiveness (X3) variable affects the Customer Satisfaction variable (Y) of 0.646 (64.6\%) (directly proportional).

Assurance variable regression coefficient value of 0.805 . This means that the Assurance variable (X4) affects the Customer Satisfaction variable (Y) of $80.5 \%$ (directly proportional). This Assurance variable is the most influential variable on the level of customer satisfaction compared to other variables. Regression coefficient value of Empathy variable is 0.698 . This means that the Empathy variable affects the Customer Satisfaction variable (Y) of 69.8\%. The independent variable is the most dominant influence on Customer Satisfaction (Y) at PT. PLN (Persero) Region S2JB Area Palembang Rayon Mariana is variable Assurance (X4). Determination Coefficient Test Results

Based on the results of the R-Square test using the help of the SPSS program, the test results obtained from the coefficient of determination are as follows :

Table 4. Determinant Coefficient Test Results

\begin{tabular}{cccccc}
\hline $\begin{array}{c}\text { Mode } \\
\mathbf{l}\end{array}$ & $\mathbf{R}$ & $\begin{array}{c}\mathbf{R} \\
\text { Square }\end{array}$ & $\begin{array}{c}\text { Adjusted } \\
\mathbf{R} \\
\text { Square }\end{array}$ & $\begin{array}{c}\text { Std. Error } \\
\text { of } \\
\text { the } \\
\text { Estimate }\end{array}$ & $\begin{array}{c}\mathbf{D} \\
\mathbf{W}\end{array}$ \\
\hline 1 & $\begin{array}{c}0,845 \\
\text { a }\end{array}$ & 0,714 & 0,607 & 0,386707 & 2,0 \\
& & & & 75 \\
\hline
\end{tabular}

Source: Data Processing Results

Based on Table 4.9. above, obtained the R-Square value of $0.714(71.4 \%)$. Based on the magnitude of the coefficient of determination it can be concluded that Customer Satisfaction can be explained by Physical Evidence, Reliability, Responsiveness, Assurance, and Empathy of $71.4 \%$; while the remaining $29.6 \%$ is explained by other factors not included in this study.

\section{Hypothesis Test Results \\ Test Results for Hypothesis F (Anova)}

Based on the results of the test using the SPSS program, the results of the F Hypothesis F (Anova) were obtained, as follows:

Table 5. Hypothesis Test Results (Anova)

\begin{tabular}{lccccc}
\hline & $\begin{array}{c}\text { Sum of } \\
\text { Squares }\end{array}$ & df & $\begin{array}{c}\text { Mean } \\
\text { Square }\end{array}$ & F & Sig. \\
\hline Regression & 13,583 & 5 & 2,717 & 62,9 &, 000 \\
& & & & 42 & \\
Residual & 4,057 & 94 & 0,043 & & \\
Total & 17,640 & 99 & & & \\
\hline
\end{tabular}

Source: Data Processing Results

Published By:

Blue Eyes Intelligence Engineering

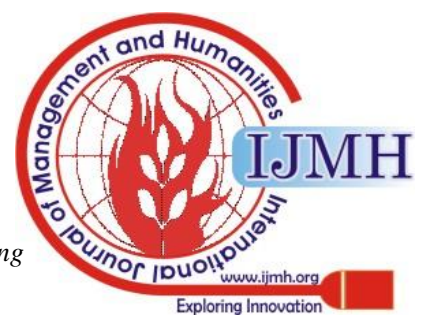


The F-table value, with a real level $(\alpha)=5 \%(0.05)$, with $\mathrm{df}=(\mathrm{n}-\mathrm{k}-1)=(100-5-1)=94$ and $\mathrm{k}=5(5 \% ; 94 ; 5)$ amounting to 2,310; so the value of F-count (4.791) > F-table $(2,310)$ or Sig F $(0,001)<\alpha(0,05)$, then $\mathrm{H} 0$ is rejected and $\mathrm{Ha}$ is accepted, meaning there is a significant effect of Tangibles, Reliability, Responsiveness, Assurance, and Empathy simultaneously on Customer Satisfaction at PT. PLN (Persero) Region S2JB Area Palembang Rayon Mariana.

\section{DISCUSSION}

\section{Discussion of the Effect of Service Quality on Customer Satisfaction}

The results of this study explain that the independent variables used in this study can increase customer satisfaction at PT. PLN (Persero) Region S2JB Area Palembang Rayon Mariana. The results of this study are in line with the theory expressed by Nasution (2012: 192), which explains that efforts to satisfy customers must face a number of challenges, namely: customer expectations that are dynamic and shaped by many factors, strategy segmentation, customer loyalty, technology utilization, complaint reluctance, and other customer satisfaction.

Based on the results of the above research, this shows that overall service quality has a great influence on customer satisfaction.

\section{CONCLUSION}

Based on the results of the discussion in the previous chapter, a number of things can be concluded, including the following :

a. There is a significant effect of simultaneous Physical Proof (Reliability), Responsiveness, Assurance, and Empathy on Customer Satisfaction at PT. PLN (Persero) Region S2JB Area Palembang Rayon Mariana.

b. There is no significant effect of Tangibles on Customer Satisfaction at PT. PLN (Persero) Region S2JB Area Palembang Rayon Mariana.

c. There is a significant influence on Reliability and Responsiveness, Assurance, and Empathy partially on Customer Satisfaction.

\section{SUGGESTION}

Based on the conclusions above, then there are some suggestions that might be useful in increasing Customer Satisfaction at PT. PLN (Persero) Region S2JB Area Palembang Rayon Mariana, namely as follows :

a. Efforts to improve Physical Evidence (Tangibles), namely maintaining $\mathrm{kWh}$ meters in customer parcels on damaged and scheduled kWh meters on an old kWh meter.

b. Efforts can be made in improving reliability, which is to ensure the availability of prepaid electricity meter kWh material so that the service process (new pairs / power changes / maintenance) is in accordance with the level of service quality.

c. Efforts can be made in improving responsiveness, namely ensuring the presence of officers in accordance with the picket schedule that has been provided so that there are no delays in repair / damage and network disturbances.

d. Efforts that can be made in improving Assurance, namely improving the quality of prepaid electricity $\mathrm{kWh}$ meters to be more resistant and strong against damage. e. Efforts can be made in improving Empathy (Emphaty) activities, making culture 3S (Smile, Greetings, Greetings) in every activity of PLN.

\section{REFERENCES}

1. Akhtar, N., Latif, M., \& Ashraf, A. (2016). The Impact of Service Quality, Customer Satisfaction and Loyalty Programs on Customer's Loyalty. International Review Of, 3(16), 200-209.

2. Court, S., \& Drive, R. (2015). Customer Statisfaction and service quality in UK ( Accepted for inclusion in the International Journal of Production and Operations Management ) University of Exeter Discussion Papers in Management Paper number 07 / 10 ISSN 1472-2939. International Journal of Production and Operations Management, 03(07).

3. Kotler, P., \& Lane, K. (2009). Manajemen Pemasaran. Jakarta: Erlangga.

4. Lekobane, K. R., \& Selelo, G. B. (2017). Effects of Service Quality on Customers Satisfaction on Botswana's Mobile Telecommunications Industry. Archives of Business Research, 5(3), 212-228. https://doi.org/10.14738/abr.53.2833

5. Sunyoto, D. (2012). Dasar-dasar Manajemen Pemasaran. Yogyakarta: CAPS.

6. Tjiptono, F. (2014). Pemasaran Jasa- Prinsip, Penerapan, dan Penelitian. Yogyakarta.

7. Tjiptono, F., \& Gregorus, C. (2011). Service, Quality \& Statisfaction (3rd ed.). Yogyakarta.

\section{AUTHORS PROFILE}

Dina Nirwana Asri Putri, Student postgraduate Magister Management at sriwijaya university, Indonesia. Email: darasaini2@gmail.com

Zakaria Wahab, Lecturer of Economic Faculty at Sriwijaya University Indonesia

Ahmad Widad, Lecturer of Economic Faculty at Sriwijaya University Indonesia

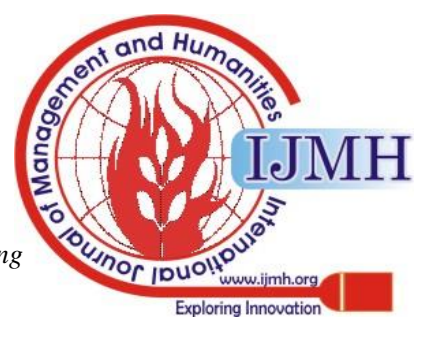

